\title{
The importance of comparative phylogeography in diagnosing introduced species: a lesson from the seal salamander,
} Desmognathus monticola

\author{
Ronald M Bonett*1, Kenneth H Kozak², David R Vieites ${ }^{1}$, Alison Bare ${ }^{3}$, \\ Jessica A Wooten ${ }^{4}$ and Stanley E Trauth ${ }^{3}$
}

Address: ${ }^{1}$ Museum of Vertebrate Zoology and Department of Integrative Biology, University of California at Berkeley, Berkeley, CA, 94720, USA, ${ }^{2}$ Department of Ecology and Evolution, Stony Brook University, Stony Brook, NY, 11794, USA, ${ }^{3}$ Department of Biological Sciences, Arkansas State University, State University, AR, 72467, USA and ${ }^{4}$ Department of Biological Sciences, University of Alabama, Tuscaloosa, AL, 35487, USA

Email: Ronald M Bonett* - ron-bonett@utulsa.edu; Kenneth H Kozak - kozak016@umn.edu; David R Vieites - vieites@berkeley.edu; Alison Bare - alisonljb@hotmail.com; Jessica A Wooten - jwooten10@yahoo.com; Stanley E Trauth - STRAUTH@astate.edu

* Corresponding author

Published: 7 September 2007

BMC Ecology 2007, 7:7 doi:10.1186/1472-6785-7-7

This article is available from: http://www.biomedcentral.com/1472-6785/7/7

(C) 2007 Bonett et al; licensee BioMed Central Ltd.

This is an Open Access article distributed under the terms of the Creative Commons Attribution License (http://creativecommons.org/licenses/by/2.0), which permits unrestricted use, distribution, and reproduction in any medium, provided the original work is properly cited.
Accepted: 7 September 2007
Received: 25 February 2007

\begin{abstract}
Background: In most regions of the world human influences on the distribution of flora and fauna predate complete biotic surveys. In some cases this challenges our ability to discriminate native from introduced species. This distinction is particularly critical for isolated populations, because relicts of native species may need to be conserved, whereas introduced species may require immediate eradication. Recently an isolated population of seal salamanders, Desmognathus monticola, was discovered on the Ozark Plateau, $\sim 700 \mathrm{~km}$ west of its broad continuous distribution in the Appalachian Mountains of eastern North America. Using Nested Clade Analysis (NCA) we test whether the Ozark isolate results from population fragmentation (a natural relict) or long distance dispersal (a human-mediated introduction).
\end{abstract}

Results: Despite its broad distribution in the Appalachian Mountains, the primary haplotype diversity of $D$. monticola is restricted to less than $2.5 \%$ of the distribution in the extreme southern Appalachians, where genetic diversity is high for other co-distributed species. By intensively sampling this genetically diverse region we located haplotypes identical to the Ozark isolate. Nested Clade Analysis supports the hypothesis that the Ozark population was introduced, but it was necessary to include haplotypes that are less than or equal to $0.733 \%$ divergent from the Ozark population in order to arrive at this conclusion. These critical haplotypes only occur in $<1.2 \%$ of the native distribution and NCA excluding them suggest that the Ozark population is a natural relict.

Conclusion: Our analyses suggest that the isolated population of $D$. monticola from the Ozarks is not native to the region and may need to be extirpated rather than conserved, particularly because of its potential negative impacts on endemic Ozark stream salamander communities. Diagnosing a species as introduced may require locating nearly identical haplotypes in the known native distribution, which may be a major undertaking. Our study demonstrates the importance of considering comparative phylogeographic information for locating critical haplotypes when distinguishing native from introduced species. 


\section{Background}

Species introduced by human activities are one of the leading threats to biodiversity [1-4]. A critical step in ameliorating the impacts and spread of introduced species is to identify and contain them in their infancy $[5,6]$. However, humans have been altering biotic patterns across the world since the "Age of Exploration" [7], and for many regions species introductions precede complete biodiversity inventories, obscuring our ability to distinguish introduced from native flora and fauna. This is potentially a very important yet time sensitive distinction, especially for isolated populations, because the alternate diagnoses suggest opposite conservation action. Isolated native populations may need special protection [8-10], while introduced species may need to be eliminated $[5,6]$. In the absence of historical information genetic data may be necessary to determine the origin of an isolated population, although pin-pointing the closest relatives in the known native distribution (to test the history of the isolate adequately) can be an endless task. Here, we show that using comparative phylogeographic patterns of taxa that are co-distributed across the known, native range of a putatively introduced population may be the most effective strategy for distinguishing native from introduced species.

The Plethodontidae is the most species rich family of salamanders $[11,12]$, and their diversity has been primarily shaped by allopatric speciation events resulting in an abundance of cryptic species and genetically distinct isolated populations [e.g., [13-16]. The plethodontid genus Desmognathus, endemic to eastern North America, includes 19 recognized species; their primary diversity is centered in the southern portion of the Appalachian Mountains [11,12] (Figure 1A). This genus is marked by great ecomorphological diversity, ranging from small, strictly terrestrial species to very large-bodied, streamdwelling predators [17-19], but most ecomorphs also contain parapatrically distributed cryptic species [20-22].

The Ozark Plateau of east-central North America is a karst uplift separated from the Appalachian Mountains by the low elevation flood plain of the Mississippi River. The Ozark Plateau harbors many endemic species, including a unique salamander fauna $[23,24]$. There are only a few historical reports of Desmognathus on the Ozark Plateau $[25,26]$, but no credence has been given to these records $[27,28]$ since no museum vouchers exist and no subsequent specimens were found for the next $40+$ years. In 2003, a very restricted, but thriving, population of Desmognathus was discovered in the western Ozarks [29]. This population is similar, both morphologically and mitochondrially, to the seal salamander (Desmognathus monticola), a large stream-dwelling species that is widespread in the Appalachian Mountains, more than $700 \mathrm{~km}$ to the east (Figure 1B). This isolated population represents either the only known, and possibly last, remnant of an entire lineage (Desmognathus) in the Ozark Plateau or an introduced species that could threaten local endemic species if it spreads (see Discussion).

There is a wealth of biogeographic evidence that suggests a relatively recent faunal connection between the Ozarks and the Appalachians, and many conspecifics or sister species of fish [30-32], crayfish [33] and salamanders $[11,34,35]$ occur across these regions. On the other hand, surveys have shown $D$. monticola to be one of the most common salamander species found in fishing bait shops [36], so this population may have been introduced by fishermen or by other human activities. Without further detailed population genetic analyses, it is not possible to support or reject either scenario.

Using NCA, based on a portion of the mitochondrial gene cytochrome oxidase-1 ( $\operatorname{cox} 1)$, we test whether this isolate is the result of a recent human-mediated introduction or represents a relict from historical faunal connections between the Appalachian Mountains and the Ozark Plateau. If the Ozark population originated through fragmentation and contraction of a previously more widespread distribution, then we would expect it to exhibit significant genetic divergence from Appalachian populations. Alternatively, if the Ozark population results from a recent introduction through human activities, we would expect little or no genetic divergence from Appalachian populations, despite the large geographic separation between these highland regions. These predictions are ideally suited for testing with Nested Clade Analysis, which uses the geographic distributions of ancestral (interior) haplotypes relative to younger (tip) ones to draw inferences about processes that have shaped spatial patterns of genetic variation.

Adequately sampling genetic diversity is critical for testing phylogeographic hypotheses $[37,38]$. Although, given the fact that genetic diversity is not always randomly distributed across a species' distribution, it can be challenging to assess sampling adequacy a priori. Our sampling includes the entire latitudinal distribution of D. monticola, with dense sampling from the southernmost extent of the Appalachian Mountains where lineage diversity is known to be high for other co-distributed taxa [39-43]. We find that the highest genetic diversity in $D$. monticola is restricted to a localized region ( $<2.5 \%$ of the distribution) in northern Georgia, and a correct diagnosis of the Ozark population is highly dependent on including critical haplotypes from this region in the NCA. We discuss our results in the context of developing sampling strategies based on comparative phylogeography of co-occurring 


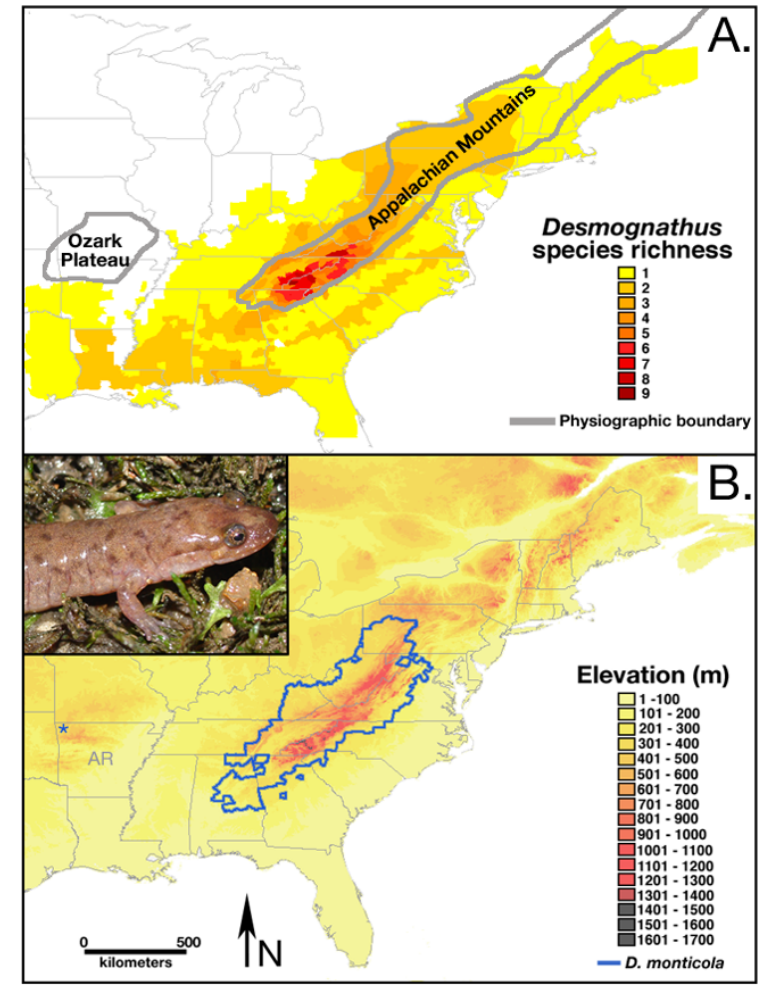

Figure I

Distribution and species richness of Desmognathus. A. Species richness of the genus Desmognathus, with the highest species diversity in the southern Appalachian Mountains. Note: Desmognathus are absent from the Ozark Plateau. B. Geographic distribution of Desmognathus monticola outlined in blue overlaid on an elevation map of eastern North America. The isolated population of $D$. monticola in the Ozarks is designated with a blue star. Inset is a photograph of an adult D. monticola from the Ozarks.

species when assessing the history of populations that are suspected of being introduced.

\section{Results}

There was no nucleotide variation in the 515 basepair (bp) cox1 fragment among our seven Ozark samples. The 100 Appalachian samples from 47 populations covering the entire latitudinal distribution of $D$. monticola represented 18 unique cox1 haplotypes (Additional File 1). The geographic distribution of haplotypes was highly disproportional, with the highest diversity centered in the southern Appalachian Mountains (Figure 2, Table 1). Appalachian haplotypes ranged from $0.000 \%$ to $2.689 \%$ divergent from the Ozark population. Haplotypes identical (zero mutational steps; $0.000 \%$ divergent) to the

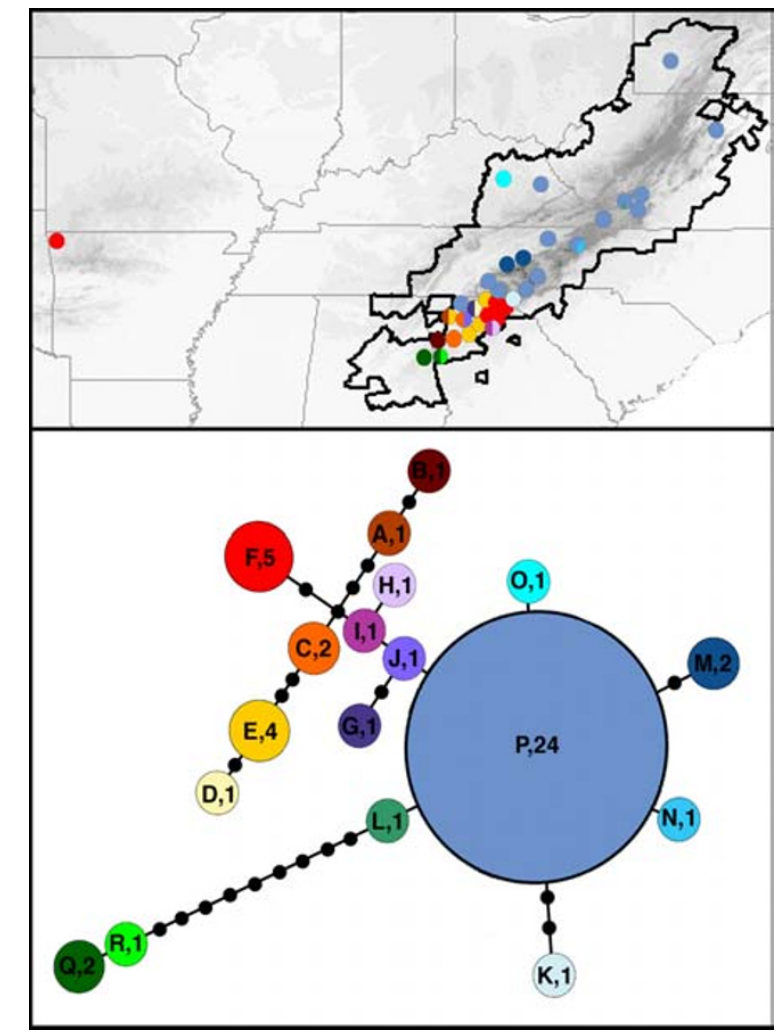

Figure 2

Geographic distribution and unrooted statistical parsimony networks for $D$. monticola haplotypes. The large majority of the geographic distribution contains only a few haplotypes (K, L, M, N, O, \& P). The Ozark haplotype (F, red) occurs in the southern Appalachians of northern Georgia amongst a great diversity of related haplotypes. Labels on the network indicate the haplotype and the number of counties where it was found (sizes of circles are also drawn proportional to this number). Colors of haplotypes correspond to pie diagrams on the map and show the frequency of haplotyope in each county sampled. Black dots on haplotype network indicate hypothetical unsampled haplotypes.

Ozark population (haplotype F) were found in the region of highest haplotype diversity in northeast Georgia. The origin of the Ozark population of D. monticola was investigated with NCA $[44,45]$ (See Methods Section). The distance among populations that have haplotype $\mathrm{F}$ is significantly large $(D c=310.58, D n=292.71$; Figure 3 ). The distance between haplotype $\mathrm{F}$ and its nearest neighbor in the network (haplotype $\mathrm{C}$ ) is also significantly large ( $\mathrm{Dc}=251.27, \mathrm{Dn}=217.20)$. NCA of the clade including haplotypes $\mathrm{C}$ and $\mathrm{F}$ (clade 2-2) indicates that the Ozark population is the result of long distance colonization (i.e., Introduction). Our path to this conclusion is as follows. All nested clades are from separate areas (i.e., there is no 
Table I: Comparison of coxI divergence between Appalachian and Ozark haplotypes. The Ozark population only contains a single haplotype $(F)$. Note the large number of haplotypes restricted to northern Georgia (GA). See Figure two for map and Additional File I for locality details.

\begin{tabular}{cccl}
\hline $\begin{array}{c}\text { Haplo } \\
\text { type }\end{array}$ & $\begin{array}{c}\text { uncorrected } p \text { to the } \\
\text { Ozark population }\end{array}$ & $\begin{array}{c}\text { Number } \\
\text { of } \\
\text { localities }\end{array}$ & States \\
\hline A & $1.222 \%$ & $\mathrm{I}$ & $\mathrm{GA}$ \\
$\mathrm{B}$ & $1.711 \%$ & $\mathrm{I}$ & $\mathrm{GA}$ \\
$\mathrm{C}$ & $0.733 \%$ & 2 & $\mathrm{GA}$ \\
$\mathrm{D}$ & $1.956 \%$ & $\mathrm{I}$ & $\mathrm{GA}$ \\
$\mathrm{E}$ & $1.467 \%$ & 4 & $\mathrm{GA}$ \\
$\mathrm{F}$ & $\mathbf{0 . 0 0 0 \%}$ & $\mathbf{5}$ & $\mathrm{AR}, \mathrm{GA}$ \\
$\mathrm{G}$ & $0.978 \%$ & $\mathrm{I}$ & $\mathrm{GA}$ \\
$\mathrm{H}$ & $0.978 \%$ & $\mathrm{I}$ & $\mathrm{GA}$ \\
$\mathrm{I}$ & $0.733 \%$ & $\mathrm{I}$ & $\mathrm{GA}$ \\
$\mathrm{J}$ & $0.978 \%$ & $\mathrm{I}$ & $\mathrm{GA}$ \\
$\mathrm{K}$ & $1.956 \%$ & $\mathrm{I}$ & $\mathrm{GA}$ \\
$\mathrm{L}$ & $1.467 \%$ & $\mathrm{I}$ & $\mathrm{VA}$ \\
$\mathrm{M}$ & $1.711 \%$ & 2 & $\mathrm{TN}$ \\
$\mathrm{N}$ & $1.467 \%$ & $\mathrm{I}$ & $\mathrm{NC}$ \\
$\mathrm{O}$ & $1.467 \%$ & $\mathrm{I}$ & $\mathrm{KY}$ \\
$\mathrm{P}$ & $1.222 \%$ & $\mathrm{I}$ & $\mathrm{GA}, \mathrm{KY}, \mathrm{NC}, \mathrm{PA}$, \\
& & & $\mathrm{TN}, \mathrm{VA}, \mathrm{WV}$ \\
$\mathrm{Q}$ & $2.934 \%$ & 2 & $\mathrm{AL}, \mathrm{GA}$ \\
$\mathrm{R}$ & $2.689 \%$ & $\mathrm{I}$ & $\mathrm{GA}$ \\
\hline
\end{tabular}

State abbreviations are as follows:

$\mathrm{AL}=$ Alabama, $\mathrm{AR}=$ Arkansas, $\mathrm{GA}=$ Georgia, $\mathrm{KY}=$ Kentucky, NC $=$ North Carolina, $\mathrm{PA}=$ Pennsylvania, $\mathrm{TN}=$ Tennessee, $\mathrm{VA}=$ Virginia, and $\mathrm{WV}=$ West Virginia.

geographic overlap between the distribution of haplotypes $\mathrm{F}$ and $\mathrm{C}$; Yes to couplet \#1). The species is present between where haplotypes $\mathrm{F}$ and $\mathrm{C}$ were found within the Appalachians (Yes to couplet \#19), and we did sample this area (Yes to couplet \#20). None of the conditions in couplets \#2 or \#11 are satisfied. There is a reversal in significance between I-T Dn and Dc values (I-T Dn $=-178 \mathrm{~S}$, $\mathrm{Dc}=251.27 \mathrm{~L}$; Yes to couplet \#12). Since the Ozark population is separated from the geographical center of other clades (Yes to couplet \#13), and there are no mutational differences between this population and some Appalachian populations, we conclude that the Ozark population arose from long distance colonization. Given the NCA evidence for restricted gene flow and dispersal within portions of the native range, and the limited dispersal capabilities of plethodontid salamanders $[46,47]$, this long-distance movement likely resulted from human activities.

In order to test the necessity of including very similar (or identical) haplotypes to determine whether the Ozark population is native or introduced, we sequentially ran additional NCAs that excluded Appalachian samples that were $0.000 \%$ (haplotype F), and $\leq 0.733 \%$ (haplotypes $\mathrm{F}$, $\mathrm{C}$, and I) divergent from the Ozark population. Excluding only identical Appalachian haplotypes (Haplotype $\mathrm{F}=$ $0.56 \%$ of the distribution), still leads to the inference that the Ozark population was introduced. However, excluding Appalachian haplotypes F, C, and I, leads to a significantly small Dc for clade 2-2 (i.e., Ozark haplotype F). Since the Ozark population is separated from the remaining haplotypes by a larger than average number of mutational steps, and is allopatric from clades $2-3$ and 2-4, this leads to the inference of allopatric fragmentation at the level of clade 3-2. This demonstrates that in this case it is necessary to locate and include in the NCA, haplotypes that are $\leq 0.733 \%$ divergent from the Ozark population, in order to properly diagnose the Ozark population as introduced. The distributions of these critical haplotypes (F, C, and I) are localized to a small region in northern Georgia that comprises $<1.2 \%$ of the geographic distribution of D. monticola (Figure 4).

\section{Discussion \\ Distinguishing native populations from human introductions}

To date most genetic studies of introduced species have focused on evolutionary genetics $[48,49]$, genetic diversity [50], hybridization [51,52], and the identification of source populations of species that are known to be introduced [e.g., [50,53-57]. The field of phylogeography has played a major role in understanding patterns of species invasions $[51,58]$. However, there are relatively few studies that have tested whether or not a given species has been introduced by human activities [59-62], and little attention has been given to the approaches and pitfalls of molecular-based identification of putative invaders $[63,64]$. Here we demonstrate a case where the correct diagnosis of an isolated population (as native or introduced) using molecular methods is highly dependent on locating and sufficiently sampling a very restricted portion of the native distribution of a wide-ranging species. We identified this region and sampled it intensively based on the biogeographic history and patterns of genetic diversity of other co-distributed fauna.

Phylogeographic analyses based on inadequate sampling can lead to spurious results $[37,38]$. For many reasons, patterns of genetic variation are often non-randomly distributed across the species landscape. Therefore, the percentage of geographic distribution sampled does not necessarily equate to the percentage of existing haplotypes sampled, making it difficult to determine when adequate sampling has been achieved. Examining patterns of genetic diversity of co-distributed species can provide clues to patterns of diversity in the species of interest [65]. Many eastern North American species show considerable concordance in phylogeographic patterns, particularly due to the effects of Pleistocene glaciation [reviewed in [39]]. One phylogeographic pattern common to many 


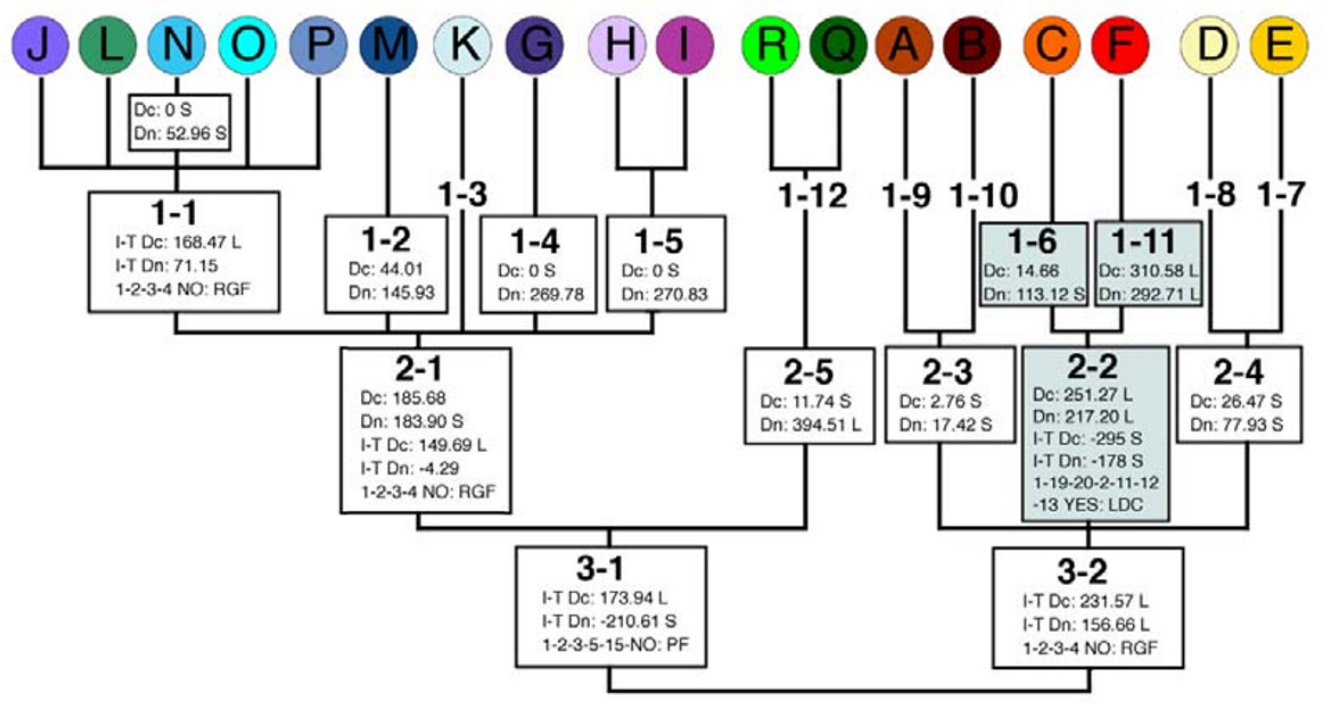

\section{Figure 3}

Graphical summary of the nested haplotype structure and NCA. Individual haplotypes are listed across the top, with increasingly more inclusive nested groups extending to the bottom. Interior haplotypes/nested groups are depicted in bold italics. Significant $D_{C}, D_{N}$, and I-T values are reported. Distances that are significantly small or large are indicated with $S$ or $L$, respectively. The path taken through the most recent version of the inference key is shown; RGF, restricted gene flow; PF, past fragmentation; LDC, long-distance colonization; RE w/PF, range expansion coupled with past fragmentation. NCA results directly relevant to the diagnosis of the Ozark population (haplotype F) are highlighted in blue.

animals, particularly salamanders, is that southern populations represent historical refugia and are genetically diverse while more northern populations underwent recent post-glacial range expansions and are often genetically uniform [e.gs., [20,39-43]. The phylogeographic patterns that we have elucidated for $D$. monticola are consistent with patterns exhibited by many co-distributed species. The large majority of the distribution of D. monticola represents a single lineage (containing the closely related haplotypes $\mathrm{K}, \mathrm{L}, \mathrm{M}, \mathrm{N}, \mathrm{O}$, and $\mathrm{P}$ ) that likely represents a recent range expansion from the southernmost highlands of the Appalachian Mountains all the way to the most northern extent of the distribution (Figure 2). The southern portion of the distribution may be a historical refuge and thus contains the highest genetic diversity. More than $50 \%$ of the cox 1 haplotype diversity of D. monticola is restricted to less than $2.5 \%$ of the current geographic distribution of the species. In this case, the source of the human-mediated Ozark introduction is derived from this genetically diverse region in the southern Appalachian Mountains. When analyzing the isolated Ozark population of $D$. monticola in terms of a broad geographic sampling of its known native distribution, but only excluding Appalachian haplotypes that are $\leq 0.733 \%$, the Ozark population appeared to be a unique historical rem- nant that deserves conservation attention (Figure 4). An analysis that contains a broad sampling from across the known native distribution, but only missing these critical haplotypes could look convincing, and subsequently lead to an incorrect diagnosis and the protection of an introduced species.

Comprehensive sampling of genetic diversity of the species' known native distribution may be essential for making an accurate assessment of the history of populations as native or introduced by humans, but exhaustive sampling may not be practical, especially when rapid identification is necessary for conservation strategies to be immediately implemented. We suggest that considering comparative phylogeographic patterns of co-distributed species can expedite an accurate diagnosis by acting as a guide to sampling the known native distribution of the species in question. For species that have undergone recent range expansions such as the one in this study, a comparative phylogeographic approach can help locate the areas of highest genetic diversity, and prevent over-sampling in genetically uniform regions. Furthermore, if phylogeographic data are available for co-distributed species with ecological requirements that are similar to those of the species in question (i.e., taxa potentially influenced by 


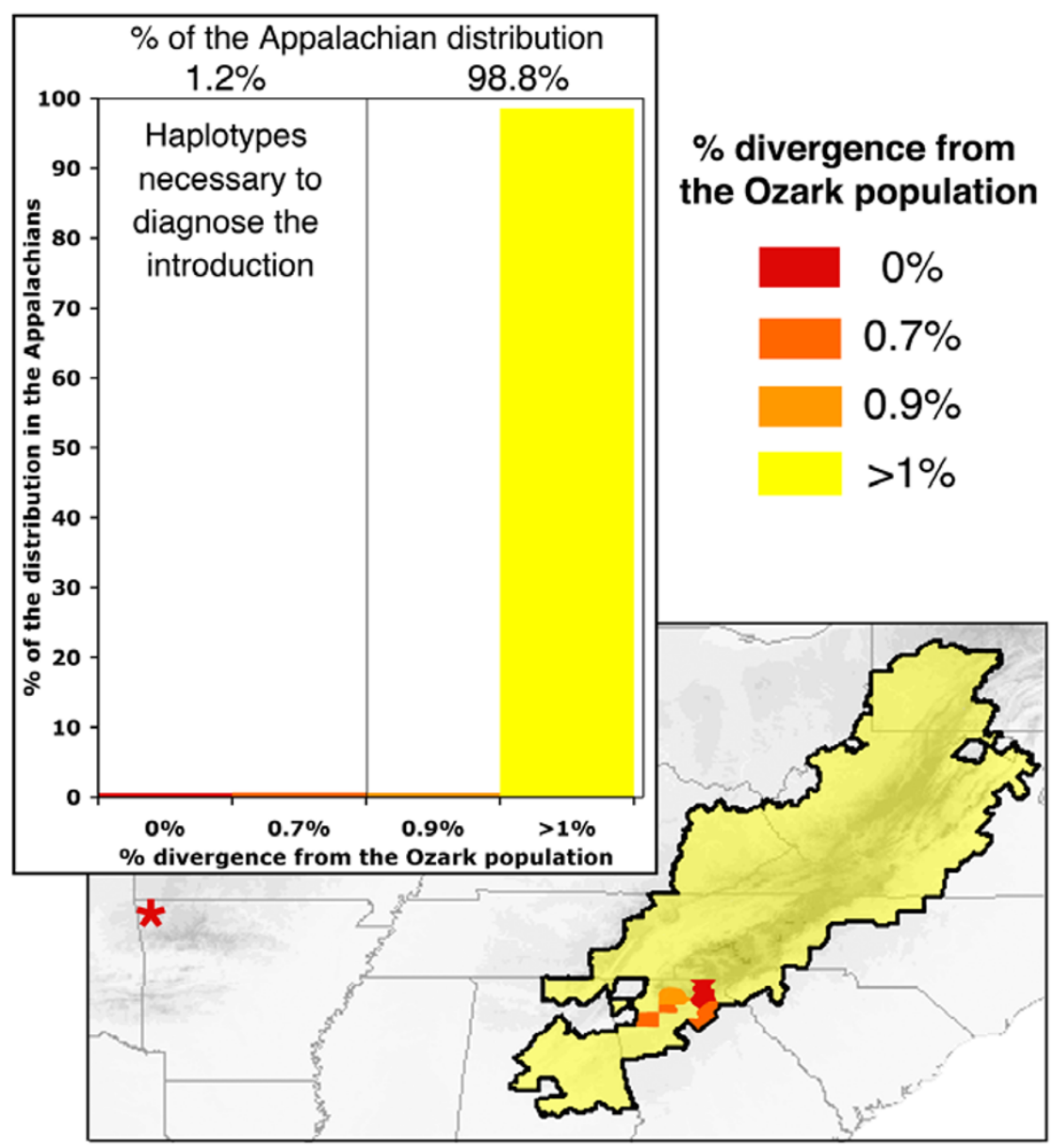

\section{Figure 4}

Percent divergence of Appalachian haplotypes to the Ozark population and their geographic distribution. Inset graph depicts the \% sequence of the Appalachian haplotypes to the Ozark population and the \% of the area of the distribution that they occur. The map shows the genetic landscape of haplotypes in relation to their divergence from the Ozark population. Note that it is necessary to include haplotypes that are $\leq 0.733 \%$ divergent from the Ozark population in order to diagnose it as introduced.

similar patterns of vicariance), this could effectively guide further sampling. For example, if the known native distribution of a terrestrial species extends across a region that is dissected by many rivers that are barriers to gene flow for other co-distributed terrestrial species, then initial analyses could compare the population in question to individuals from the land between each river (i.e., to each primary biogeographic subunit). This could help to narrow down which part of the distribution is genetically most similar to populations in question, and could help to focus subsequent sampling.

\section{Introduced Ozark Desmognathus}

Based on our analyses it appears that the population of $D$. monticola recently discovered in the Ozark Plateau is introduced. We found that this population shares identical cox1 haplotypes with populations of D. monticola from four counties in the northeastern corner of the state of Georgia in the southern Appalachians ( 1000 km away). Nested Clade Analysis of the cox 1 fragment shows that this highly disjunct population results from a long distance dispersal (human-mediated introduction). Furthermore, we sequenced an additional $1.6 \mathrm{~kb}$ of a more variable region of mitochondrial DNA, upstream from our cox1 fragment, for select individuals. This region includes the gene NADH dehydrogenase subunit 2, tRNA ${ }^{\mathrm{Trp}}$, tRNAAla, tRNAAsn, tRNACys, tRNATyr, the origin for light-strand replication, and the beginning of $\operatorname{cox} 1$. We found only a single nucleotide substitution between the Ozark population and our samples from northeast Georgia (i.e., in total only one substitution in $>2 \mathrm{~kb}$ of mitochondrial DNA). 
How did a southern Appalachian salamander get transported to the western Ozarks? In the southeastern United States, stream-dwelling plethodontid salamanders of the genera Desmognathus, Gyrinophilus, and Pseudotriton are vernacularly referred to as "spring lizards", and are commonly used as fishing bait for catching large species of centrarchid fishes such as largemouth bass (Micropterus salmoides). "Spring lizards" are collected from the wild and sold in bait shops by the thousands [66]. In fact, surveys of bait shops in northern Georgia (the source area of the Ozark introduction) found $D$. monticola to be the most common salamander sold [36]. Unfortunately, there is little information on the broader sales and distribution of "spring lizards" to investigate whether a bait bucket was the source of the Ozark introduction. This is not the only long-distance introduction of a salamander in the United States. North American tiger salamanders such as the barred tiger salamanders (Ambystoma mavortium) are also extensively collected and sold as fishing bait in the central and western United States. Populations of A. mavortium have been introduced to localities in California ( 2000 $\mathrm{km}$ from their native distribution) where they hybridize with the rare California tiger salamander, Ambystoma californiense [52]. Another case is of the wandering salamander, Aneides vagrans, which was accidentally introduced to western Canada from central California through shipments of bark from oak trees in the early 1900s [60]. These salamanders have become well established and very widespread in coastal British Colombia and Vancouver, but are not noted to be invasive [60].

Do introduced Desmognathus monticola have a negative ecological impact in the Ozark Plateau? The Ozark Plateau is home to four stream/spring-dwelling species of plethodontid salamanders of the genus Eurycea:E. lucifuga, E. longicauda melanopleura, E. spelaea, and E. tynerensis, and the latter two (E. spelaea and E. tynerensis) are actually species groups that represent a major endemic Ozark radiation [24]. Although stream-dwelling Desmognathus and Eurycea are broadly sympatric in the Appalachian and Ouachita Mountains, the Ozark Plateau is geologically distinctly different from these regions [67] and contains very different stream habitats [68-70]. The Ozark Plateau is well drained and is very dry during the summer months. Moist streamside habitats that are important for some metamorphosing species of Eurycea as well as D. monticola are quite limited. Desmognathus monticola are large territorial salamanders and are very aggressive towards both conspecific and heterospecific stream-dwelling salamanders [71]. It has been hypothesized that in the southern Appalachians, where up to seven species of Desmognathus occur sympatrically [72], ecological boundaries between congeners are maintained by aggressive interference and predation [73-78]. Desmognathus monticola is larger and more robust than any of the Ozark Eurycea, and large adults would likely be the competitively-superior salamanders in a spring or stream. Although predation by large stream-dwelling Desmognathus on other salamanders in the wild is rare [79], this species has been shown to displace heterospecifics from the most suitable moist habitats [80]. Therefore, the presence of D. monticola could have a negative impact on Ozark Eurycea simply by excluding them from moist habitats at the periphery of springs and streams, a habitat feature that can be quite limited in arid areas of the Ozark Plateau.

Ozark Desmognathus monticola are currently known from only two locations. The salamanders included in this study are from a small spring ca. 1 meter wide that issues from the underside of a dirt bank and flows approximately 8.5 meters before reaching a much larger stream (Spavinaw Creek). Since the original discovery in 2003 we have visited this site four times and have found up to 25 individuals, ranging in size from very small newly metamorphosed juveniles, to very large adults $(75+\mathrm{mm} \mathrm{SVL})$, in a single survey. Among the largest individuals, we found one gravid female, $55 \mathrm{~mm} \mathrm{SVL}$, with enlarged (ca. 2.5-3.0 $\mathrm{mm}$ in diameter) ovarian follicles (ca. $35 \mathrm{ova}$ ). Therefore, it appears that D. monticola are breeding and reproducing at this location. Recently, a second Ozark $D$. monticola location was discovered by members of the Arkansas Herpetological Society. Three adult D. monticola were found in a small spring entering Spavinaw Creek $\left(36.4030^{\circ} \mathrm{N}, \quad 94.3569^{\circ} \mathrm{W}\right)$ approximately $2.5 \mathrm{~km}$ upstream of the locality included in our analyses (K. Roberts personal communication 2006). We presently know little about the abundance of Desmognathus monticola in the Ozarks and additional research on the ecological interactions between this introduced species and co-occurring species of Eurycea are necessary to determine the level of impact that it has on local salamander fauna.

\section{Conclusion}

Our analyses of mitochondrial DNA indicate that the highly disjunct population of seal salamanders, Desmognathus monticola, recently discovered on the Ozark Plateau, is not native to the region. This population may need to be extirpated because of its potential negative impacts on endemic Ozark stream-dwelling salamanders. This conclusion could only be realized once nearly identical haplotypes from the known native distribution were included in our analyses. Locating the most genetically similar individuals (the putative source population) in the known native distribution of a species to effectively test the origin of an isolated population can be a laborintensive and costly undertaking. We propose that considering comparative phylogeographic patterns can greatly facilitate this process and expedite diagnoses of native and introduced species. 


\section{Methods \\ Sampling}

Salamanders from the Ozark population were collected from 30-September-2003 to 4-April-2005. Due to the limited distribution of the Ozark Desmognathus, vouchers were only taken for the first six individuals and were deposited at Arkansas State University Museum of Vertebrates (ASUMZ 28083-28086; 28156; 29032). Tail tips were taken in the field from subsequent specimens because at the time we did not know the species was introduced. These were compared to a large database of $D$. monticola cox1 sequences from GenBank $[81,82]$, specimens collected from 8-May-2000 to 16-May-2002 by KHK that were deposited in the University of Minnesota's John Ford Bell Museum (JFBM), two tissue samples from the Museum of Vertebrate Zoology, University of California, Berkeley (MVZ), and samples collected in northern Georgia by JAW from 12-January-2006 and 26-March-2006 that were deposited in the MVZ (Additional File 1).

\section{DNA isolation, amplification and sequencing}

DNA was extracted from fresh frozen tissues and ethanol preserved tissues using Qiagen DNeasy extraction kits. A portion of the mitochondrial gene cytochrome oxidase 1 (cox1, 515 bp not including primers) was amplified using the primers COX1F (5'-GGTATTGAGGTTTCGGTCTG-3') and COX1R (5'-CTTAGTCTCTTAATTCGAGC-3') [81] with standard protocols. PCR products were run out on $1.5 \%$ agarose gels. Successful amplifications were cleaned with a Millipore $\mathrm{PCR}_{96}$ cleanup kit (Montáge ${ }^{\mathrm{TM}}$ ) or EXOSAPIT (USB Corp.). Big Dye (ABI) was used for cycle sequencing reactions sequenced on an ABI 3730 capillary sequencer. Sequencher ${ }^{\mathrm{Tm}} 3.1$ (Gene Codes Corp.) was used to align and edit sequences. The alignment was unambiguous and the translation was checked in MacClade [83]. Sequences were deposited in GenBank; accession numbers are provided in Additional File 1. For the analyses we trimmed the fragment to 409 bp so that we could utilize sequences from GenBank. PAUP* $4.0 \mathrm{~b} 10$ [84] was used to calculate uncorrected pairwise sequence divergences among populations. The sizes of the whole distribution of D. monticola, was based on the Global Amphibian Assessment [85]. We omitted a disjunct isolate from southern Alabama because preliminary mitochondrial DNA evidence suggests that it is a different species $[81,82]$. The size and percentage of the distribution of selected haplotypes was estimated based on the size of the county where they occur. This is actually a slight over estimate as multiple haplotypes occur in some counties, so in this species locating specific haplotypes to properly diagnose the introduction should be at least as difficult as we suggest if not more.

\section{Nested clade analysis}

The origin of the Ozark population of D. monticola was investigated with Nested Clade Analysis $[44,45]$ in order to test between two alternate hypotheses: past fragmentation (a natural historical relict) or long distance colonization (human-mediated introduction). Haplotype networks were constructed with statistical parsimony method implemented in TCS [86], and the haplotype networks were converted into nested clades $[87,88]$. The coordinates used in the analyses were either determined with a Garmin XL Global Positioning System (GPS) in the field, or extrapolated from topographical maps. The only locality information available for some of the GenBank sequences was the state and county, so we estimated the coordinates of the center point of the county for those samples. GeoDis version 2.0 [89] was used to calculate (1) the clade distance Dc, which measures the average distance of haplotypes in a nested group from its geographical center, (2) the nested clade distance Dn, which measures how far a haplotype group is from the geographic center of other groups with which it is nested, and 3) the average Dc and Dn separating interior and tip groupings of haplotypes. To test whether the geographic distributions of haplotypes were more widespread or restricted than expected by chance, we used a categorical permutation contingency analysis. The most likely historical and recurrent processes responsible for statistically significant patterns of phylogeographic variation were inferred using the revised inference key 11 November 2005 [45].

\section{Abbreviations}

ASUMZ, Arkansas State University Museum of Zoology; bp, basepairs; cox1, cytochrome oxidase 1; Dc, clade distance; Dn, nested clade distance; I-T, interior to tip; JFBM, John Ford Bell Museum; MVZ, Museum of Vertebrate Zoology; NCA, nested clade analysis; PF, past fragmentation; RE, range expansion; RGF, restricted gene flow.

\section{Authors' contributions}

$\mathrm{RMB}$ coordinated the study, collected and analyzed sequence data, and primarily prepared the manuscript. KHK contributed many Appalachian samples, performed the NCA, and contributed to the preparation of the manuscript. DRV assisted in collecting sequence data and contributed to the focus and preparation of the manuscript. $\mathrm{AB}$ discovered the Ozark population of D. monticola and participated in subsequent field trips. JAW collected invaluable material from across the state of Georgia and edited the manuscript. SET made the initial identification of AB's discovery and coordinated additional fieldwork and contributed to the preparation of the manuscript. All authors read and approved the final manuscript. 


\section{Additional material}

\section{Additional file 1}

Locality information, museum and Genbank accession numbers for the $\mathrm{D}$. monticola samples used in this study.

Click here for file

[http://www.biomedcentral.com/content/supplementary/14726785-7-7-S1.doc]

\section{Acknowledgements}

We thank Kelly Irwin of the Arkansas Game and Fish for facilitating the investigation of the Ozark population and issuing collecting permits. We are grateful to D. Buckley, C. Camp, B. Cockrum, S. Eagle, I. Martínez-Solano, and $B$. Wheeler for joining us in the field during collecting. Additional tissues samples used in this study were provided by the Museum of Vertebrate Zoology and we thank Brian Lin was for his help in the lab at the MVZ. We thank Paul Chippindale for use of his lab at the University of Texas at Arlington where RMB collected a couple preliminary sequences. We also thank K. Roberts and the Arkansas Herpetological Society for sharing information on the additional Ozark $D$. monticola location that they recently discovered. S. Emel, E. Timpe, M. Tumeo, D. Wake, M. Wake, and two anonymous reviewers provided valuable comments on the manuscript. This study was funded by the Charles Ash and Bruce Family Scholarships from Highlands Biological Station, NSF DBI-0434728 to KHK, and NSF AmphibiaTree Grant EF-0334939 to D. B. Wake and M. H. Wake for which RMB and DRV were postdocs.

\section{References}

I. Walker B, Steffen W: An overview of the implications of global change for natural and managed terrestrial ecosystems. Conservation Ecology 1997, I:2.

2. Wilcove DS, Rothstein D, Dubowe J, Phillips A, Losos E: Quantifying threats to imperiled species in the United States. BioScience 1998, 48:607-6I5.

3. Sala OE, Chapin FS, Armesto JJ, Berlow E, Bloomfield J, Dirzo R, Huber-Sanwald E, Huenneke LF, Jackson RB, Kinzig A, Leemans R, Lodge DM, Mooney HA, Oesterheld M, Poff NL, Sykes MT, Walker $\mathrm{BH}$, Walker M, Wall DH: Global Biodiversity Scenarios for the Year 2 I00. Science 2000, 287: I770-I774.

4. Clavero M, García-Berthou E: Invasive species are a leading cause of animal extinctions. Trends in Ecology and Evolution 2005, 20: II0.

5. Ruesink JL, Parker IM, Groom MJ, Kareiva PM: Reducing the risks of nonindigenous species introductions: guilty until proven innocent. BioScience 1995, 45:465-477.

6. Simberloff $D$ : How much information on population biology is needed to manage introduced species? Conservation Biology 2003, I 7:83-92.

7. Mooney HA, Cleland EE: The evolutionary impact of invasive species. Proceedings of the National Academy of Sciences 2001, 98:5446-545I.

8. Lesica $\mathrm{P}$, Allendorf FW: When are peripheral populations valuable for conservation? Conservation Biology 1995, 9:753-760.

9. Moritz C: Defining 'evolutionary significant units' for conservation. Trends in Ecology and Evolution 1994, 9:373-375.

10. Moritz C: Strategies to protect biological diversity and the evolutionary processes that sustain it. Systematic Biology 2002, 5 I:238-254.

II. Petranka JW: Salamanders of the United States and Canada Washington, DC USA: Smithsonian Institution Press; 1998.

12. AmphibiaWeb: Information on amphibian biology and conservation [http://amphibiaweb.org/]. Berkeley, California

13. García-Paris M, Good DA, Parra-Olea G, Wake DB: Biodiversity of Costa Rican salamanders: Implications of high levels of genetic differentiation and phylogeographic structure for species formation. Proceedings of the National Academy of Sciences USA 2000, 97:1640-1647.

14. Chippindale PT: Species boundaries and species diversity in the central Texas hemidactyliine plethodontid salamanders, genus Eurycea. In The Biology of Plethodontid Salamanders Edited by: Bruce RC, Jaeger RG, Houck LD. (New York, USA): Kluwer Academic, Plenum Publishers; 2000: I49-I65.

15. Kozak KH, Weisrock DW, Larson A: Rapid lineage accumulation in a non-adaptive radiation: Phylogenetic analysis of diversification rates in eastern North American woodland salamanders (Plethodontidae: Plethodon). Proceedings of the Royal Society of London B 2006, 273:539-546.

16. Wake DB: Problems with species: patterns and processes of species formation in salamanders. Annals of the Missouri Botanical Garden 2006, 93:8-23.

17. Hairston NG: Species packing in the salamander genus Desmognathus : what are the interspecific interactions involved? The American Naturalist 1980, I I 5:354-366.

18. Bruce RC: Life-history perspective of adaptive radiation in desmognathine salamanders. Copeia 1996, I 996:783-790.

19. Kozak KH, Larson A, Bonett RM, Harmon LJ: Phylogenetic analysis of ecomorphological divergence, community structure, and diversification rates in dusky salamanders (Plethodontidae: Desmognathus). Evolution 2005, 59:2000-2016.

20. Tilley SG, Mahoney MJ: Patterns of genetic differentiation in salamanders of the Desmognathus ochrophaeus complex (Amphibia: Plethodontidae). Herpetological Monographs 1996, 10:1-42.

21. Bonett RM: Analysis of the contact zone between Desmognathus fuscus fuscus and Desmognathus fuscus conanti (Caudata: Plethodontidae). Copeia 2002, 2002:344-355.

22. Crespi EJ, Rissler LJ, Browne RA: Testing Pleistocene refugia theory: phylogeographical analysis of Desmognathus wrighti, a high-elevation salamander in the southern Appalachians. Molecular Ecology 2003, I 2:969-984.

23. Dowling HG: Geographic relations of Ozarkian amphibians and reptiles. The Southwestern Naturalist 1956, I:I74-I89.

24. Bonett RM, Chippindale PT: Speciation, phylogeography and evolution of life history and morphology in plethodontid salamanders of the Eurycea multiplicata complex. Molecular Ecology 2004, I 3: I 189-1203.

25. Burt CE: Further records of the ecology and distribution of the Amphibians and Reptiles of the Middle West. American Midland Naturalist 1935, 16:31 I-336.

26. Smith CC: Notes on the salamanders of Arkansas No. 2. The status of Desmognathus in Arkansas. Proceedings of the Arkansas Academy of Science 1960, 14:14-19.

27. Dowling HG: A review of the amphibians and reptiles of Arkansas. Occasional Papers of the University of Arkansas Museum |957, 3:|-5|.

28. Means DB: Desmognathus brimleyorum. Catalogue of the American Amphibians and Reptiles 1999, 682:I-4.

29. Trauth SE, Robison HW, Plummer MV: The amphibians and reptiles of Arkansas (Fayetteville, AR, USA): The University of Arkansas Press; 2004.

30. Mayden RL: Vicariance biogeography, parsimony, and evolution in North American freshwater fishes. Systematic Zoology 1988, 37:329-355.

31. Strange RM, Burr BM: Intraspecific phylogeography of North American highland fishes: A test of the Pleistocene vicariance hypothesis. Evolution 1997, 5 I:885-897.

32. Hardy ME, Grady JM, Routman EJ: Intraspecific phylogeography of the slender madtom: the complex evolutionary history of the Central Highlands of the United States. Molecular Ecology 2002, I I:2393-2403.

33. Crandall KA, Tempelton AR: The zoogeography and centers of origin of the crayfish subgenus Procericambarus (Decapoda: Cambaridae). Evolution 1999, 53:123-134.

34. Merkle DA, Guttman SI: Geographic variation in the cave salamander Eurycea lucifuga. Herpetologica I977, 33:3 I3-32I.

35. Routman EJ, Wu R, Templeton AR: Parsimony, molecular evolution, and biogeography: the case of the North American giant salamander. Evolution 1994, 48: $1799-1809$.

36. Jensen BJ, Waters C: The 'spring lizard' bait industry in the state of Georgia, USA. Herpetological Review 1999, 30:20-21. 
37. Masta SE, Laurent NM, Routman EJ: Population genetic structure of the toad Bufo woodhousii : an empirical assessment of the effects of haplotype extinction on nested cladistic analysis. Molecular Ecology 2003, I 2: I 54 I - I 554.

38. Morando M, Avila LJ, Sites JW Jr: Sampling strategies for delimiting species: genes, individuals, and populations in the Liolaemus elongatus -kriegi complex (Squamata: Liolaemidae) in Andean - Patagonian South America. Systematic Biology 2003, 52:159-185.

39. Soltis DE, Morris AB, McLachlan JS, Manos PS, Soltis PS: Comparative phylogeography of unglaciated eastern North America. Molecular Ecology 2006, I 5:426 I-4293.

40. Highton R, Webster TP: Geographic protein variation and divergence in populations of the salamander Plethodon cinereus. Evolution 1976, 30:33-45.

4I. Brant SV, Ortí G: Phylogeography of the northern short-tailed shrew, Blarina brevicauda (Insectivora: Soricidae): past fragmentation and post glacial recolinization. Molecular Ecology 2003, I 2:1435-1449.

42. Zamudio KR, Savage WK: Historical isolation, range expansion, and secondary contact of two highly divergent mitochondrial lineages in spotted salamanders (Ambystoma maculatum). Evolution 2003, 57:|63|-1652.

43. Kozak KH, Blaine RA, Larson A: Gene lineages and eastern North American palaeodrainage basins: phylogeography and speciation in salamanders of the Eurycea bislineata species complex. Molecular Ecology 2006, I 5:191-207.

44. Templeton AR, Routman E, Phillips C: Separating population structure from population history: a cladistic analysis of the geographical distribution of mitochondrial DNA haplotypes in the Tiger Salamander, Ambystoma tigrinum. Genetics 1995 , I 40:767-782.

45. Templeton AR: Nested clade analyses of phylogeographic date: testing hypotheses about gene flow and population history. Molecular Ecology 1998, 7:381-397.

46. Larson A, Wake DB, Yanev K: Measuring gene flow among populations having high levels of genetic fragmentation. Genetics 1 984, 106:293-308.

47. Smith MA, Green DM: Dispersal and the metapopulation paradigm in amphibian ecology and conservation: are all amphibian populations metapopulations? Ecography 2005, 28: I I0-I 28.

48. Novak SJ, Mack RN: Genetic variation in Bromus tectorum comparison between native and introduced populations. Heredity 1993, 7I:167-176.

49. Facon B, Pointier JP, Glaubrecht M, Poux C, Jarne P, David P: A worldwide molecular phylogeography approach to biological invasions in parthenogenetic thiarid snails. Molecular Ecology | 2:3027-304|.

50. Kolbe JJ, Glor RE, Schettino LR, Lara AC, Larson A, Losos JB: Genetic variation increases during biological invasion by a Cuban lizard. Nature 2004, 431: 177- |81.

51. Gaskin JF, Schaal BA: Hybrid Tamarix widespread in US invasion and undetected in native Asian range. Proceedings of the National Academy of Sciences 2002, 99: I I 256- I I 259.

52. Riley SPD, Shaffer HB, Voss SR, Fitzpatrick BJ: Hybridization between a rare native tiger salamander (Ambystoma californiense) and its introduced congener. Ecological Applications 2003, I3:1263-1275.

53. Bonizzoni M, Guglielmino CR, Smallridge CJ, Gomulski M, Malacrida $A R$, Gasperi $G$ : On the origins of medfly invasion and expansion in Australia. Molecular Ecology 2004, I 3:3845-3855

54. Benavides P, Vega FE, Romero-Severson J, Bustillo AE, Stuart J]: Biodiversity and biogeography of an important inbred pest of coffee, coffee berry borer (Coleoptera: Curculionidae: Scolytinae). Annals of the Entomological Society of America 2005, 98:359-366.

55. Städler T, Frye M, Neiman M, Lively CM: Mitochondrial haplotypes and the New Zealand origin of colonial European Potamopyrgus, an invasive aquatic snail. Molecular Ecology 2005 , 1 4:2456-2473.

56. Durka W, Bossdorf $O$, Prati D, Auge $H$ : Molecular evidence for multiple introductions of garlic mustard (Alliaria petiolata, Brassicaceae) to North America. Molecular Ecology 2005 | 4: | 697-1706.

57. Gaskin JF, Zhang DY, Bon MC: Invasion of Lepidium draba (Brassicaceae) in the western United States: distributions and origins of chloroplast DNA haplotypes. Molecular Ecology 2005, | 4:233|-234|.

58. Schaal BA, Gaskin JF, Caicedo AL: Phylogeography, haplotype trees, and invasive plant species. Journal of Heredity 2003, 94:197-204

59. Geller JB, Walton ED, Grosholz ED, Ruiz GM: Cryptic invasions of the crab Carcinus detected by molecular phylogeography. Molecular Ecology 1997, 6:901-906.

60. Jackman TR: Molecular and historical evidence for the introduction of clouded salamanders (genus Aneides) to Vancouver Island, British Columbia, Canada, from California. Canadian Journal of Zoology 1998, 76:1570-1580.

61. Wares JP, Goldwater DS, Kong BY, Cunningham CW: Refuting a controversial case of a human-mediated marine species introduction. Ecology Letters 2002, 5:577-584.

62. Genner JM, Michel E, Erpenbeck D, De Voogd N, Witte F, Pointier J: Camouflaged invasion of Lake Malawi by an oriental gastropod. Molecular Ecology 2004, I 3:2 I 35-2 I 4I.

63. Geller JB: Molecular approaches to the study of marine biological invasions. In Molecular Zoology Edited by: Ferraris JD, Palumbi SR. New York, USA: Wiley; 1996:I 19-I 32.

64. Armstrong KF, Ball SL: DNA barcodes for biosecurity: invasive species identification. Philosophical Transactions of the Royal Society B 2005, 360: 1813-1823.

65. Pauley GB, Piskurek O, Shaffer HB: Phylogeographic concordance in the southeastern United States: the flatwoods salamander,Ambystoma cingulatum. Molecular Ecology 2007, 16:4I5-429.

66. Jensen JB, Camp CD: Human exploitation of amphibians: direct and indirect impacts. In Amphibian Conservation Edited by: Semlitsch RD. Washington DC, USA: Smithsonian Institution; 2003:199-213.

67. Fenneman NM: Physiography of Eastern United States McGraw-Hill Inc., New York and London; 1938.

68. Quinn JH: Plateau surfaces of the Ozarks. Proceedings of the Arkansas Academy of Science 1958, I I:36-43.

69. Unklesbay AG, Vineyard JD: Missouri Geology, Three Billion Years of Volcanoes, Seas, Sediment, and Erosion University of Missouri Press, Columbia, MO; 1992

70. Bonett RM, Chippindale PT: Streambed microstructure predicts evolution of development and life history mode in the plethodontid salamander Eurycea tynerensis. BMC Biology 2006, 4:6.

7I. Keen WH, Sharp D: Responses of a plethodontid salamander to conspecific and congeneric intruders. Animal Behaviour 1984 32:58-65.

72. Bruce RC: Evolution of ecological diversification in desmognathine salamanders. Herpetological Review I99|, 22:44-45.

73. Kleeberger SR: A test of competition in two sympatric populations of desmognathine salamanders. Ecology 1984 65:1846-1856.

74. Carr DE, Taylor DH: Experimental evaluation of population interactions among three sympatric species of Desmognathus. Journal of Herpetology 1985, 19:507-5 I4.

75. Hairston NG: Species packing in Desmognathus salamanders: experimental demonstration of predation and competition. The American Naturalist 1986, I 27:266-291.

76. Southerland MT: Behavioral interactions among four species of the salamander genus Desmognathus. Ecology 1986, 67:|75-|8|.

77. Southerland MT: Coexistence of three congeneric salamanders: the importance of habitat and body size. Ecology 1986 67:721-728.

78. Grover MC: Determinants of salamander distributions along moisture gradients. Copeia 2000, 2000:156-168.

79. Camp CD: The status of the black-bellied salamander (Desmognathus quadramaculatus) as a predator of heterospecific salamanders in Appalachian streams. Journal of Herpetology 1997, 31:613-616.

80. Keen WH: Habitat selection and interspecific competition in two species of plethodontid salamanders. Ecology 1982 63:94-102.

8I. Rissler LJ, Taylor DR: The phylogenetics of desmognathine salamander populations across the southern Appalachians. Molecular Phylogenetics and Evolution 2003, 27:197-21I.

82. Rissler LJ, Wilbur HM, Taylor DH: The influence of ecology and genetics on behavioral variation in salamander populations 
across the eastern continental divide. The American Naturalist 2004, 164:20I-2I3.

83. Maddison DR, Maddison WP: MacClade. Analysis of phylogeny and character evolution, v. 4.03 Sunderland (Massachusetts, USA): Sinauer Associates; $200 \mathrm{I}$.

84. Swofford DL: PAUP*: Phylogenetic Analysis Using Parsimony and Other Methods. v. 4.0. b/O Sunderland (Massachusetts, USA): Sinauer Associates; 2001.

85. Global Amphibian Assessment [http://www.globalamphibi ans.org]

86. Clement M, Posada D, Crandall KA: TCS: a computer program to estimate gene genealogies. Molecular Ecology 2000, 9:1657-1660.

87. Templeton AR, Boerwinkle E, Sing CF: A cladistic analysis of phenotypic associations with haplotypes inferred from restriction endonuclease mapping. I. Basic theory and an analysis of alcohol dehydrogenase activity in Drosophila. Genetics 1987, I I 7:343-35I.

88. Templeton AR, Sing CF: A cladistic analysis of phenotypic associations with haplotypes inferred from restriction endonuclease mapping, IV nested analysis with uncertainty and recombination. Genetics 1993, 134:659-669.

89. Posada D, Crandall KA, Templeton AR: GeoDis: a program for the cladistic nested analysis of the geographical distribution of genetic haplotypes. Molecular Ecology 2000, 9:487-488.

Publish with Bio Med Central and every scientist can read your work free of charge

"BioMed Central will be the most significant development for disseminating the results of biomedical research in our lifetime."

Sir Paul Nurse, Cancer Research UK

Your research papers will be:

- available free of charge to the entire biomedical community

- peer reviewed and published immediately upon acceptance

- cited in PubMed and archived on PubMed Central

- yours - you keep the copyright

Submit your manuscript here:

http://www.biomedcentral.com/info/publishing_adv.asp
BiolMedcentral 